\title{
Employee Net Promoter Score (eNPS) as a Single-item Measure of Employee Work Satisfaction An Empirical Evidence from Companies Operating in Poland
}

Piotr Sedlak iD

Cracow University of Economics

\section{Introduction}

Living in the modern world means a high probability of being invited to a survey and facing the question: "How likely is it that you would recommend X company to a friend or colleague?". Those respondents taking part in an employee satisfaction survey may have heard the version "[...] would you recommend work at our company to a friend or colleague [...]". This single question concerning the willingness to recommend is a base for the Net Promoter Score ${ }^{1}$ indicator. It became so popular in customer surveys that it could claim the title of The Holy Grail of social research. Does it deserve it?

This text will focus on NPS methodology and its possibility to be adapted in an employee satisfaction survey. An important task is checking what the "would recommend" question really measures. A fair part will be devoted to deliberation about the development of the NPS and showing how the "would recommend" question works in practice of the employee satisfaction surveys.

1 Net Promoter $^{\oplus}$, Net Promoter System ${ }^{\oplus}$, Net Promoter Score ${ }^{\circledR}$ and NPS ${ }^{\oplus}$ are registered trademarks of Bain \& Company, Inc., Fred Reichheld and Satmetrix Systems, Inc. 


\section{Who created the NPS and why it became so popular?}

The NPS was created by Frederick F. Reichheld ${ }^{2}$ who published in Harvard Business Review the text with convincing title: The One Number You Need to Grow ${ }^{3}$. Reichheld was ensuring his readers that: "you don't need expensive surveys and complex statistical models. You only have to ask your customers one question"4. Having a good professional reputation ${ }^{5}$ and being sure of his research was probably one reason of Reichheld's success. The other reasons may be the simplicity of the NPS, the easiness in understanding for managers and the focus on business growth. The item created by Reichheld was even called "the ultimate question"6. There is much research confirming the success of the NPS in the business world. For example, in one piece of research, $71 \%$ of the large companies in the sample were using the NPS ${ }^{7}$ or another research showing that the majority of Customers Experience Directors use the NPS as one of the key indicators ${ }^{8}$.

\section{Development of the NPS}

Reichheld, in his text, is rather modest when it comes to the description of his methodology. He mentions that the research took 2 years and "the 'would recommend' question generally proved to be the most effective in determining loyalty and predicting growth" 9 . What we know, is that the author of the NPS was looking for correlation between the survey questions and business results based on over 4000 surveys.

2 With assistance of his team at Bain company.

3 F. Reichheld, The One Number You Need to grow, "Harvard Business Review", December 2003, vol. 81(12), pp. 46-54, https://pubmed.ncbi.nlm.nih.gov/14712543/ (accessed: 7.12.2019).

4 Ibidem, p. 1.

5 D.B. Grisaffe, Questions about the Ultimate Question: Conceptual Considerations in Evaluating Reichheld's Net Promoter Score (Nps), "Journal of Consumer Satisfaction, Dissatisfaction \& Complaining Behavior” 2007, vol. 20, pp. 36-53.

6 F.F. Reichheld, S.R. Covey, The ultimate question: Driving good profits and true growth, vol. 211, Harvard Business School Press, Boston 2006.

7 B. Temkin, Is Net Promoter Score A Savior Or A Demon?, 2015, https://experiencematters.bl og/2015/07/09/is-net-promoter-score-a-savior-or-a-demon/ (accessed: 7.12.2019).

8 A. Pogrebniak, 15 Net Promoter Score Statistics You Need to Know in 2019, Lumoa 2018, Research, https://lumoa.me/blog/net-promoter-score-statistics (accessed: 7.12.2019).

9 F. Reichheld, The One Number..., p. 3. 
Although linking survey results to actual companies' results and customers behaviour is surely a good idea, there is a statement of Reichheld's which can cause confusion:

[...] my colleagues and I looked for a correlation between survey responses and actual behavior - repeat purchases, or recommendations to friends and peers - that would ultimately lead to profitable growth. Based on information from 4,000 consumers, we ranked a variety of survey questions according to their ability to predict this desirable behavior ${ }^{10}$.

Interestingly, that actual recommendations to friends and peers was treated as a depend variable. It seems obvious that the question about the willingness of such a recommendation happened to be a good predictor of such behaviour. It is not a mistake. The same information was later repeated in the Reichheld's article: "The data allowed us to determine which survey questions had the strongest statistical correlation with repeat purchases or referrals"11. There was no information which of the output (repeated purchases or referrals) was more important. There is also no information about the correlation indicator.

\section{The scale}

In the question that the NPS is based on (How likely is it that you would recommend X company to a friend or colleague?), an 11 point scale is used. The respondents mark their willingness of recommendation from 0 to 10, where 10 means "extremely likely" to recommend, five means neutral, and 0 means "not at all likely". Reichheld and his team noticed that the customers (or respondents) can be divided into 3 groups. Based on that, he created a quite strict rule how to characterize them. Depending on the answer, the respondents were categorized as "promoters" in the case of those who answer 10 and 9, "passively satisfied" refers to those who marked 8 and 7 and those who chosen from 6 to 0 are called "detractors". Taking only the 2 highest answers to describe "promoters" was in Reichheld's opinion the solution for the tendency of people to give rather positive answers in such surveys. This decision however, leads to an asymmetry during the final score computation. The score of the eNPS indicator is counted as the percentage of promotes deducted by percentage of detractors. So theoretically the eNPS scores can be from $-100 \%$ (only detractors) to $+100 \%$ (only promoters).

10 Ibidem, p. 5.

11 Ibidem. 
How likely is it that you would recommend product $X$ to a friend or colleague? not at all likely \begin{tabular}{|l|l|l|l|l|l|l|l|l|l|l|l}
0 & 0 & 1 & 2 & 3 & 4 & 5 & 6 & 7 & 8 & 9 & 10 \\
\hline
\end{tabular}

Figure 1. Example of NPS question and scale

Source: own work.

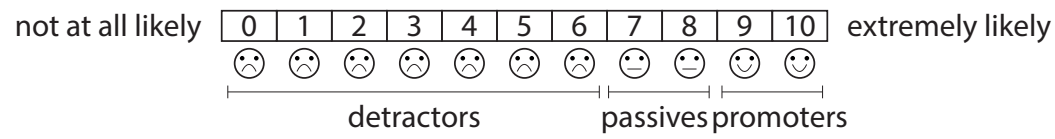

Figure 2. Mechanics of calculating the NPS indicator

Source: own work.

Is 11 points a good choice? Reichheld has not explained why the question was developed with $0-10$ scale. There is a long debate among researchers of how many points the scale should have. Five points is believed to be enough for general questions ${ }^{12}$. Most of the research found by the author of this text suggest using scales consisting from 5 to 7 point. Of course, it must be kept in mind the purpose of the survey, the content of the question itself, and the statistical operations to be undertaken. Fortunately, it is not a decision for a lifetime, and in many cases a procedure of rescaling can be used ${ }^{13}$. Another issue is that fully labeling the scale (which is not the case in the NPS) is believed to bring positive impact on research quality ${ }^{14}$.

\section{Criticism of the NPS}

There is as much enthusiasm in the business world ${ }^{15}$ as criticism about the NPS in science. First, there is no agreement on the fact that the NPS is the most important and only indicator to measure ${ }^{16}$ as Reichheld was implying originally. Secondly, many researchers failed to replicate original results and therefore found the

12 D.F. Birks, N.K. Malhotra, Marketing Research, An Applied Approach, Pearson Education Limited, Harlow 2005.

13 J. Dawes, Do data characteristics change according to the number of scale points used? An experiment using 5-point, 7-point and 10-point scales, "International Journal of Market Research" 2008, vol. 50(1), pp. 61-104, https://doi.org/10.1177/147078530805000106

14 J. Eutsler, B. Lang, Rating scales in accounting research: The impact of scale points and labels, "Behavioral Research in Accounting" 2015, vol. 27(2), pp. 35-51, https://doi.org/10.2308/br ia-51219

15 For example: K. Appold, Do You Know Your NPS Score? The new metric to watch, "Managed Healthcare Executive", March 2018, pp. 12-15.

16 D.B. Grisaffe, Questions about the Ultimate Question... 
NPS as a poor predictor of customer loyalty and customer satisfaction ${ }^{17}$. Perhaps, the harshest words were used by Sharp, who called Reichheld's work a snake oil and fake science ${ }^{18}$. In other articles, it was pointed out that there was no consideration of research bias during NPS development ${ }^{19}$. Among other criticism we may find that the NPS is focused on the user, not exactly a person who make buying decision $^{20}$.

An important factor we should keep in mind is the influence of national culture on the NPS. Originally the indicator was developed in the USA. Americans are the nation of optimists and for example Europeans are more modest in describing the positive view of something ${ }^{21}$. There are opinions that in Europe, the NPS should be measured differently and those who gave 10 and 9 but also 8 should be promoters and detractors should be limited only to those who gave 5 or less on the scale 22 .

\section{Employee Net Promoter Score (eNPS) and Employee Satisfaction}

In the literature there is not much written about the Employee Net Promotor Score (eNPS) ${ }^{23}$. What we know for sure is that the idea behind the eNPS is to ask employees how likely they would recommend their company as an employer. The measurement method, the definition of detractors and promoter remains the same ${ }^{24}$.

17 K. Kristensen, J. Eskildsen, Is the NPS a trustworthy performance measure?, "The TQM Journal" 2014, vol. 26(2), pp. 202-214, https://doi.org/10.1108/TQM-03-2011-0021

18 B. Sharp, Net promoter score fails the test, "Marketing Research" 2006, vol. 20, no. 4, pp. 28-30.

19 T.L. Keiningham et al., A Longitudinal Examination of Net Promoter and Firm Revenue Growth, "Journal of Marketing" 2007, no. 71 (July), pp. 39-51.

20 N.I. Fisher, R.E. Kordupleski, Good and bad market research: A critical review of Net Promoter Score, "Applied Stochastic Models in Business and Industry" 2019, vol. 35(1), pp. 138-151, https://doi.org/10.1002/asmb.2417

21 J. Keller, What Makes Americans So Optimistic, 2015, https://www.theatlantic.com/politi cs/archive/2015/03/the-american-ethic-and-the-spirit-of-optimism/388538/ (accessed: 7.12.2019).

22 O. Faltejsková, L. Dvořáková, B. Hotovcová, Net promoter score integration into the enterprise performance measurement and management system - A way to performance methods development, "E a M: Ekonomie a Management" 2016, vol. 19(1), pp. 93-107, https://doi.org /10.15240/tul/001/2016-1-007

23 For 27.12.2019, scholar.google found 143 results for "employee net promoter score" phrase compering to 9150 for "net promoter score".

24 B.J. Kaufman et al., Who's responsible for employee engagement?, "Bain Company Materials" 2013, pp. 1-12, https://www.bain.com/contentassets/47694dff757b45c0b1bb34ebad6b9f c9/bain_brief_whos_responsible_for_employee_engagement.pdf (accessed: 7.12.2019). 
Before answering the question if the eNPS may be used to measure job satisfaction, it is good to clarify the latter.

So, what exactly is job satisfaction? On an everyday basis, satisfaction would be connected with a positive, pleasant feeling, often the word satisfaction is connected with fulfillment. There is an important component of emotions when we speak about work satisfaction. Lock briefly described it as "pleasurable or positive emotional state resulting from the appraisal of one's job or job experiences" 25 . Having satisfaction defined as an emotional state, it has to be remembered that it is only part of the whole story. Satisfaction is in fact an attitudinal construct reflecting one's evaluation of his or her job ${ }^{26}$. The same opinion is presented by Stample and Higgins, who treats satisfaction as a positive attitude towards work and duties $^{27}$. The term attitude encompasses affect, behavior, and cognition ${ }^{28}$ which confirms that satisfaction is rather a multidimensional construct.

\section{Research Methodology}

The author has conducted the employee satisfaction surveys for several companies. In this paper there will be presented parts of this research. Presented data was gathered in 2019 in three different companies. To ensure data confidentiality, further in the text these firms will be referred to as Company $\mathrm{A}(N=\mathrm{ca} .6000)$, Company $\mathrm{B}(N=$ ca. 100$)$ and Company $\mathrm{C}(N=\text { ca. } 400)^{29}$. The companies were operating in Poland and all the surveys were conducted in Polish. In each case, all the employees employed, at the moment of the research, were asked to participate in the surveys. The respondents received an invitation to a CAWI (Computer Assisted Web Interviewing) survey, sent to the company's email address. The average response rate in these 3 surveys was $63 \%$. The structure of surveys was different in all the companies.

25 E.A. Locke, The nature and causes of job satisfaction, [in:] M.D. Dunnette (ed.), Handbook of industrial and organizational psychology, Rand McNally, Chicago 1976, p. 1304.

26 R. Lies, T.A. Judge, An experience-sampling measure of job satisfaction and its relationships with affectivity, mood at work, job beliefs, and general job satisfaction, "European Journal of Work and Organizational Psychology" 2004, no. 13, p. 368.

27 D.S. Staples, C.A. Higgins, A Study of the Impact of Factor Importance Weightings on Job Satisfaction Measures, "Journal of Business and Psychology" 1998, vol. 13(2), pp. 211-232.

28 S.J. Breckler, Empirical validation of affect, behavior, and cognition as distinct components of attitude, "Journal of Personality and Social Psychology" 1984, vol. 47(6), pp. 1191-1205, https://doi.org/10.1037/0022-3514.47.6.1191

29 The sample size was rounded down to nearest hundret, in order ensure anonimity of the companies. Further all computations were done on exact data. $\mathrm{N}$ shows actual, gathered numer of answers. It is not the size of the company. 


\section{An Empirical Results of how eNPS Works}

In the surveyed companies, except company B, the whole spectrum of answers was used by the respondents.

Table 1. The distribution of the answers to eNPS question in company A, B and C (in percent)

\begin{tabular}{|c|c|c|c|}
\hline The eNPS answer & The company A & The company B & The company C \\
\hline 0 & 14 & 0 & 1 \\
\hline 1 & 5 & 4 & 3 \\
\hline 2 & 7 & 1 & 4 \\
\hline 3 & 8 & 2 & 8 \\
\hline 4 & 6 & 2 & 13 \\
\hline 5 & 13 & 11 & 14 \\
\hline 6 & 8 & 11 & 20 \\
\hline 7 & 11 & 22 & 16 \\
\hline 8 & 12 & 25 & 7 \\
\hline 9 & 7 & 15 & 100 \\
\hline 10 & 9 & 9 & $M=6,2$ \\
\hline Total & 100 & 100 & $S D=2,3$ \\
\hline Distribution statistics & $M=5,1$ & $M=7,1$ & $-35 \%$ \\
\hline eNPS score & $S D=3,2$ & $S D=2,0$ & $-6 \%$ \\
\hline
\end{tabular}

Source: prepared by the author.

Looking at the answers distribution, it can be seen that there is no common pattern, or common peaks. In the case of the company B, $82 \%$ of the respondents chose the score 6 or higher, the mean result was 7.1. This can be interpreted as at least a good situation. However, the eNPS score (\% promotors - \% detractors) is minus $6 \%$, so below zero, which may be understood as something going wrong. Neither of the companies described in this paper have a positive eNPS value. The author had opportunities to visit company B and conduct some interviews with managers and line employees. The qualitative data confirms that the opinion about the company among its employees was good or even very good. Clearly the way of counting the eNPS score percentage of people who chose 2 values (in the scale 10 and 9) deducted by the percentage of people who chose 7 values (from 0 to 6 ) is hard to agree on, and can be misleading for eNPS users. It should be borne in mind that the research was conducted in Poland and the culture influence on the eNPS results ${ }^{30}$.

The eNPS question, in the case of all the surveyed companies, has proven to highly corelate with items concerning the general opinion about work satisfaction and with the whole work satisfaction scales. As all the scale items cannot be disclosed,

30 J. Kaufman et al., Who's responsible... 
the following text will focus only on items treated as separate entities. Described correlation suggest that the eNPS can be used as a single-item work satisfaction measure. Although such simplification causes information loss and due to the fact that there are no other possibilities, this solution should work on a sufficient level when it relates to measuring work satisfaction and engagement ${ }^{31}$.

Table 2. Spearman's Correlation Matrix for Question Asked in company A

\begin{tabular}{|l|c|c|c|}
\cline { 2 - 4 } \multicolumn{1}{c|}{} & $\begin{array}{c}\text { In general, } \\
\text { I am satisfied with } \\
\text { my job }\end{array}$ & $\begin{array}{c}\text { I see my future in this } \\
\text { organization }\end{array}$ & eNPS \\
\hline $\begin{array}{l}\text { In general, } \\
\text { I am satisfied with } \\
\text { my job }\end{array}$ & 1.0 & 0.74 & 0.62 \\
\hline $\begin{array}{l}\text { I see my future in this } \\
\text { organization }\end{array}$ & & 1.0 & 0.68 \\
\hline eNPS & & & 1.0 \\
\hline
\end{tabular}

Source: prepared by the author; $p<0.05, N=$ ca. 6000 .

Table 3. Spearman's Correlation Matrix for Question Asked in company B

\begin{tabular}{|l|c|c|c|c|c|}
\cline { 2 - 6 } \multicolumn{1}{c|}{} & $\begin{array}{c}\text { I have a feeling } \\
\text { of professional } \\
\text { satisfaction }\end{array}$ & $\begin{array}{c}\text { I like } \\
\text { my job }\end{array}$ & $\begin{array}{c}\text { The company } \\
\text { I work for is a good } \\
\text { employer }\end{array}$ & $\begin{array}{c}\text { I often think } \\
\text { about changing } \\
\text { my job }\end{array}$ & eNPS \\
\hline $\begin{array}{l}\text { I have a feeling } \\
\text { of professional } \\
\text { satisfaction }\end{array}$ & 1.0 & 0.60 & 0.43 & -0.57 & 0.55 \\
\hline I like my job & & 1.0 & 0.43 & -0.44 & 0.60 \\
\hline $\begin{array}{l}\text { The company } \\
\text { I work for is a good } \\
\text { employer }\end{array}$ & & 1.0 & -0.56 & 0.63 \\
\hline $\begin{array}{l}\text { I often think about } \\
\text { changing my job }\end{array}$ & & & & 1.0 & -0.62 \\
\hline eNPS & & & & & 1.0 \\
\hline
\end{tabular}

Source: prepared by the author; $p<0.05, N=$ ca. 100 .

The research of Legerstee provides similar results to the material gathered by the author. What is important is that Legerstee also measured the employee engagement which corelated with the eNPS even higher than work satisfaction ${ }^{32}$. Engage-

31 K. Kulikowski, Measurement of work engagement with single-item measure, "Polish Psychological Bulletin" 2018, vol. 49(4), pp. 406-415, https://doi.org/10.24425/119509

32 T. Legerstee, Asking employees "the ultimate question": Developing the Employee Promoter Score, series “Public Administration”, 2013, September 6, http://hdl.handle.net/2105/17875 (accessed: 7.12.2019). 
ment is also considered an attitude 33 but puts more emphasis on behavioural. In the surveys used in this text, there was no possibility to extract engagement components in order to have a chance of establishing if the eNPS predicts work engagement better than work satisfaction.

Table 4. Spearman's Correlation Matrix for Question Asked in company C

\begin{tabular}{|l|c|c|c|c|}
\hline & $\begin{array}{c}\text { The company I work for } \\
\text { is a good employer }\end{array}$ & $\begin{array}{c}\text { I like } \\
\text { my job }\end{array}$ & $\begin{array}{c}\text { I have a feeling of profes- } \\
\text { sional satisfaction }\end{array}$ & eNPS \\
\hline $\begin{array}{l}\text { The company } \\
\text { I work for is a good } \\
\text { employer }\end{array}$ & 1.00 & 0.42 & 0.56 & 0.67 \\
\hline I like my job & & 1.0 & 0.59 & 0.52 \\
\hline $\begin{array}{l}\text { I have a feeling } \\
\text { of professional } \\
\text { satisfaction }\end{array}$ & & & 1.0 & 0.66 \\
\hline eNPS & & & & 1.0 \\
\hline
\end{tabular}

Source: prepared by the author; $p<0.05, N=$ ca. 400 .

\section{Conclusions}

The extraordinary popularity of the NPS question resulted in market demand for a similar construction in employee satisfaction and engagement research. In the author opinion, the eNPS item is good for a general opinion evaluation. Still many differently constructed questions may lead to similar results. Using a single-item measure provides information about general opinion but does not give the company's managers any further information. The manager will know if his team is happy or not, but will not have access to the reason of such an opinion. The eNPS alone will not help to improve the situation in the company as it is not directed at any factors causing satisfaction or dissatisfaction.

On the plus side of the eNPS, there is certainly simplicity. The question does not require any special instructions for respondents, it is easily understood by management. An exception is the score itself which may be below 0 in situations when the majority of the people chose, for example, 7 and 8 on the 0 to 10 scale. This last issue in the authors opinion is the biggest disadvantage of the eNPS, especially when used by people who do not know how the score is calculated.

33 W.B. Schaufeli, What is engagement?, [in:] C. Truss et al. (eds), Employee Engagement in Theory and Practice, Routledge, London 2013, https://www.wilmarschaufeli.nl/publications/Sc haufeli/414.pdf (accessed: 7.12.2019). 
References

Appold K., Do You Know Your NPS Score? The new metric to watch, "Managed Healthcare Executive", March 2018, pp. 12-15.

Birks D.F., Malhotra N.K., Marketing Research, An Applied Approach, Pearson Education Limited, Harlow 2005.

Breckler S.J., Empirical validation of affect, behavior, and cognition as distinct components of attitude, "Journal of Personality and Social Psychology" 1984, vol. 47(6), pp. 1191-1205, https:// doi.org/10.1037/0022-3514.47.6.1191

Dawes J., Do data characteristics change according to the number of scale points used? An experiment using 5-point, 7-point and 10-point scales, "International Journal of Market Research" 2008, vol. 50(1), pp. 61-104, https://doi.org/10.1177/147078530805000106

Eutsler J., Lang B., Rating scales in accounting research: The impact of scale points and labels, "Behavioral Research in Accounting" 2015, vol. 27(2), pp. 35-51, https://doi.org/10.2308 /bria-51219

Faltejsková O., Dvořáková L., Hotovcová B., Net promoter score integration into the enterprise performance measurement and management system - A way to performance methods development, "E a M: Ekonomie a Management" 2016, vol. 19(1), pp. 93-107, https://doi.org /10.15240/tul/001/2016-1-007

Fisher N.I., Kordupleski R.E., Good and bad market research: A critical review of Net Promoter Score, "Applied Stochastic Models in Business and Industry" 2019, vol. 35(1), pp. 138-151, https://doi.org/10.1002/asmb.2417

Grisaffe D.B., Questions about the Ultimate Question: Conceptual Considerations in Evaluating Reichheld's Net Promoter Score (Nps), "Journal of Consumer Satisfaction, Dissatisfaction \& Complaining Behavior" 2007, vol. 20, pp. 36-53.

Kaufman J., Markey R., Burton S.D., Azzarello D., Who's responsible for employee engagement?, "Bain Company Materials" 2013, pp. 1-12, https://www.bain.com/contentassets/47694dff 757b45c0b1bb34ebad6b9fc9/bain_brief_whos_responsible_for_employee_engagement .pdf (accessed: 7.12.2019).

Keiningham T.L., Cooil B., Andreassen T.W., Aksoy L., A Longitudinal Examination of Net Promoter and Firm Revenue Growth, “Journal of Marketing” 2007, no. 71 (July), pp. 39-51.

Keller J., What Makes Americans So Optimistic, 2015, https://www.theatlantic.com/politics/arch ive/2015/03/the-american-ethic-and-the-spirit-of-optimism/388538/ (accessed: 7.12.2019).

Kristensen K., Eskildsen J., Is the NPS a trustworthy performance measure?, "The TQM Journal" 2014, vol. 26(2), pp. 202-214, https://doi.org/10.1108/TQM-03-2011-0021

Kulikowski K., Measurement of work engagement with single-item measure, "Polish Psychological Bulletin" 2018, vol. 49(4), pp. 406-415, https://doi.org/10.24425/119509

Legerstee T., Asking employees "the ultimate question": Developing the Employee Promoter Score, series “Public Administration”, 2013, September 6, http://hdl.handle.net/2105/17875 (accessed: 7.12.2019).

Lies R., Judge T.A., An experience-sampling measure of job satisfaction and its relationships with affectivity, mood at work, job beliefs, and general job satisfaction, "European Journal of Work and Organizational Psychology" 2004, no. 13, pp. 367-389.

Locke E.A., The nature and causes of job satisfaction, [in:] M.D. Dunnette (ed.), Handbook of industrial and organizational psychology, Rand McNally, Chicago 1976, pp. 1297-1349.

Pogrebniak A., 15 Net Promoter Score Statistics You Need to Know in 2019, Lumoa 2018, Research, https://lumoa.me/blog/net-promoter-score-statistics (accessed: 7.12.2019).

Reichheld F., The One Number You Need to grow, "Harvard Busines Review", December 2003, vol. 81(12), pp. 46-54, https://pubmed.ncbi.nlm.nih.gov/14712543/ (accessed: 7.12.2019). 
Reichheld F.F., Covey S.R., The ultimate question: Driving good profits and true growth, vol. 211, Harvard Business School Press, Boston 2006.

Schaufeli W.B., What is engagement?, [in:] C. Truss, K. Alfes, R. Delbridge, A. Shantz, E. Soane (eds), Employee Engagement in Theory and Practice, Routledge, London 2013, https://www .wilmarschaufeli.nl/publications/Schaufeli/414.pdf (accessed: 7.12.2019).

Sharp B., Net promoter score fails the test, "Marketing Research" 2006, vol. 20, no. 4, pp. 28-30. Staples D.S., Higgins C.A., A Study of the Impact of Factor Importance Weightings on Job Satisfaction Measures, "Journal of Business and Psychology" 1998, vol. 13(2), pp. 211-232.

Temkin B., Is Net Promoter Score A Savior Or A Demon?, 2015, https://experiencematters.blog/20 15/07/09/is-net-promoter-score-a-savior-or-a-demon/ (accessed: 7.12.2019).

\section{Abstract}

The goal of the article was to evaluate the pros and cons of using the eNPS indicator and its possible adaptation in employee satisfaction surveys.

The author conducted 3 independent surveys on over 6500 employees in 3 different companies. The eNPS results were correlated with questions concerning the general opinion about work and the employer.

The eNPS indicator was proven to highly correlate with items describing the general employee opinion about work satisfaction. The numerical value of the indicator itself is considered by the author as misleading due to asymmetry in the classification of positive and negative opinions.

Keywords: NPS, Employee Net Promoter Score, eNPS, work satisfaction 